\title{
Aggregate supply response in Algerian agriculture: The Error Correction Model applied to selected crops
}

\author{
Mohamed Amine Benmehaia*
}

\author{
DOI: $10.30682 / \mathrm{nm} 2101 \mathrm{f}$ \\ JEL codes: Q11, Q18
}

\begin{abstract}
This paper examines aggregate supply response of 19 selected crops in Algerian agriculture during the 1966-2018 period by employing cointegration analysis and Error Correction Model (ECM). It tests whether there has been a long-run equilibrium relationship between agricultural outputs and prices, besides a confirmation about the responsiveness of agricultural supply to economic incentives (prices). Findings indicate that the long-run elasticities of all selected crops with respect to prices are statistically significant and mostly low, whereas short-run elasticities are lower, which appeals to the adequacy of adjustment to economic incentives. Furthermore, the results of the ECM confirmed the positive responsiveness to prices with differential rates of adjustment for selected crops, ruling out the applicability of a presumed perverse supply response in Algerian agriculture.
\end{abstract}

Keywords: Aggregate supply response, Crops, Price, Cointegration, ECM, Algeria.

\section{Introduction}

Over the past fifty years, the agricultural sector has played a changing role in the Algerian economy. As a result, agricultural production has been strongly influenced through pricing and subsidy policies which have not achieved the expected results. It turns out that the poor performance recorded over such long run period is due to the alteration of the incentive structures of agricultural production. The more interesting aspect, in the context of Mediterranean agriculture, is that price volatility affects the food security (Lacirignola et al., 2015) and harms the performances of poor small farmers. Therefore, a detailed and in-depth examination of the agri- cultural supply in Algerian agriculture is needed. In order to do so, supply response modeling is a tool largely used to evaluate the effectiveness and success of pricing policies regarding farm resources allocation, the role of the agricultural sector, and provides insightful assessments for formulation of economic policy in agricultural production sector.

To the extent that studies on agricultural supply response are almost absent in Algeria, this study is an attempt to examine the responsiveness of Algerian agricultural production to changes in economic incentives during 1966-2018 period (by taking into account the non-stationarity of time series involved in estimation). However, the aim of the study is to test whether there is a

\footnotetext{
* Department of Agricultural Sciences, University of Biskra, Biskra, Algeria.

Corresponding author: ma.benmehaia@univ-biskra.dz
} 
cointegrated relationship between some selected crops production and their own prices, by using the Error Correction Model (ECM) approach as the more general approach in modeling agricultural supply response than the extensively used Nerlovian partial adjustment model approach. In other words, do Algerian farmers respond normally to economic incentives (prices)?

Insofar as there are no recent studies which answer this question in the Algerian context, economic theory offers a set of hypotheses which have been submitted repeatedly to empirical verification around the world. In developing countries, the hypothesis that has been approved by earlier empirical studies claims the perverse effect of farmers towards economic incentives ${ }^{1}$ (or at least non-response at all). The proponents of this hypothesis were not completely wrong. It turns out that they neglected the environment and the economic system in which farmers live. As concluded by Ghafouri (1988), as the only study of the agricultural supply response in Algeria, the institutional subset of constraints can be summarized in market imperfections that would prevent the underdeveloped agriculture from exhibiting a significant response to price changes.

This study uses a sophisticated methodology (a cointegration analysis followed by an ECM) on official data (provided from the FAO) to confirm that Algerian farmers do respond significantly or at least becomes more responsive to economic incentives.

The paper is organized as follows. Section 2 presents briefly the study context and the research hypothesis for the subject of agricultural supply response. Section 3 explores the research methodology and the ECM approach. Section 4 reports and discuss the main results of the study. Section 5 concludes.

\section{Agricultural supply response: study context and hypothesis}

One of the salient features of the Algerian agriculture is its relative importance in terms of the positive trend of the gross production value (reaching 16220 million constant USD in 2018) along with its value added as shown in Figure 1. On the other hand, the share of value add-

Figure 1 - The evolution of the value added and the gross production value of agriculture in constant 2005 million US\$ (FAO statistical database, 2020).

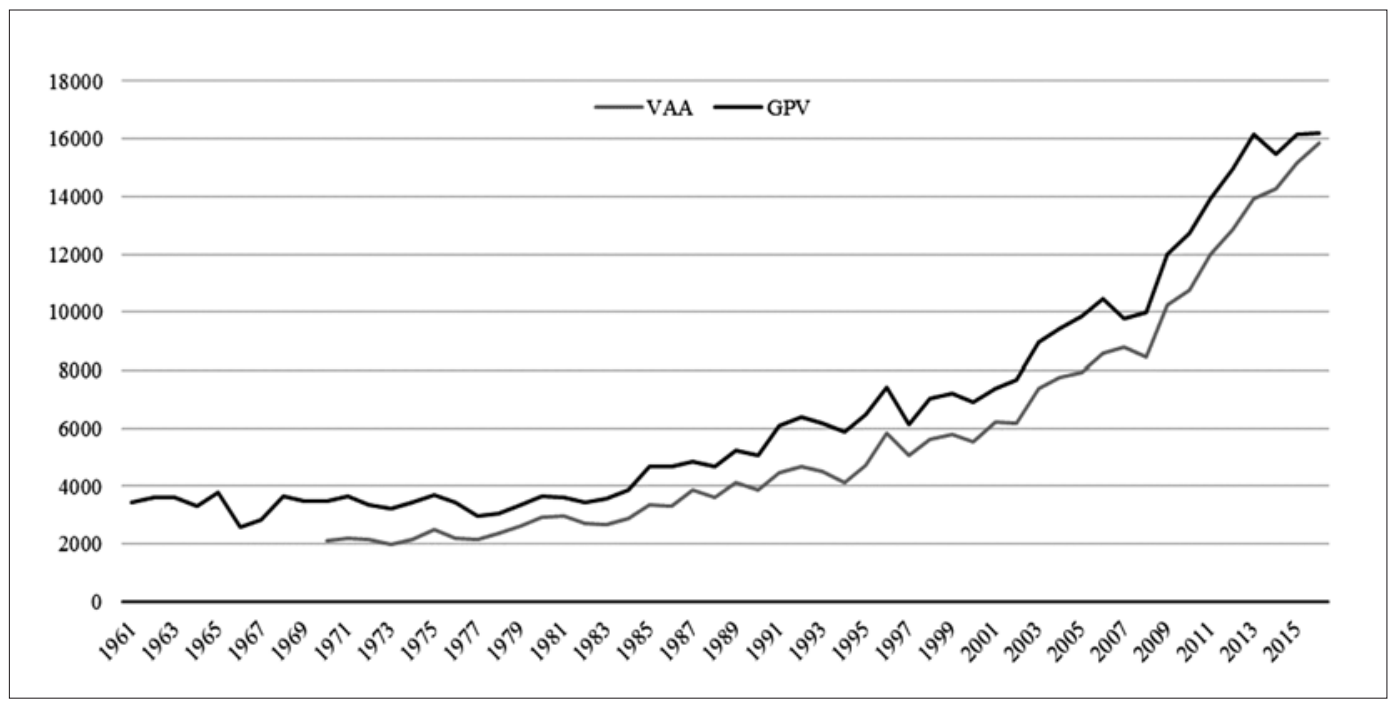

1 For the arguments in favor of this hypothesis, see Ozanne, 1999. 
Figure 2 - The evolution of the share of value added of agriculture in GDP of Algeria (FAO statistical database, 2020).

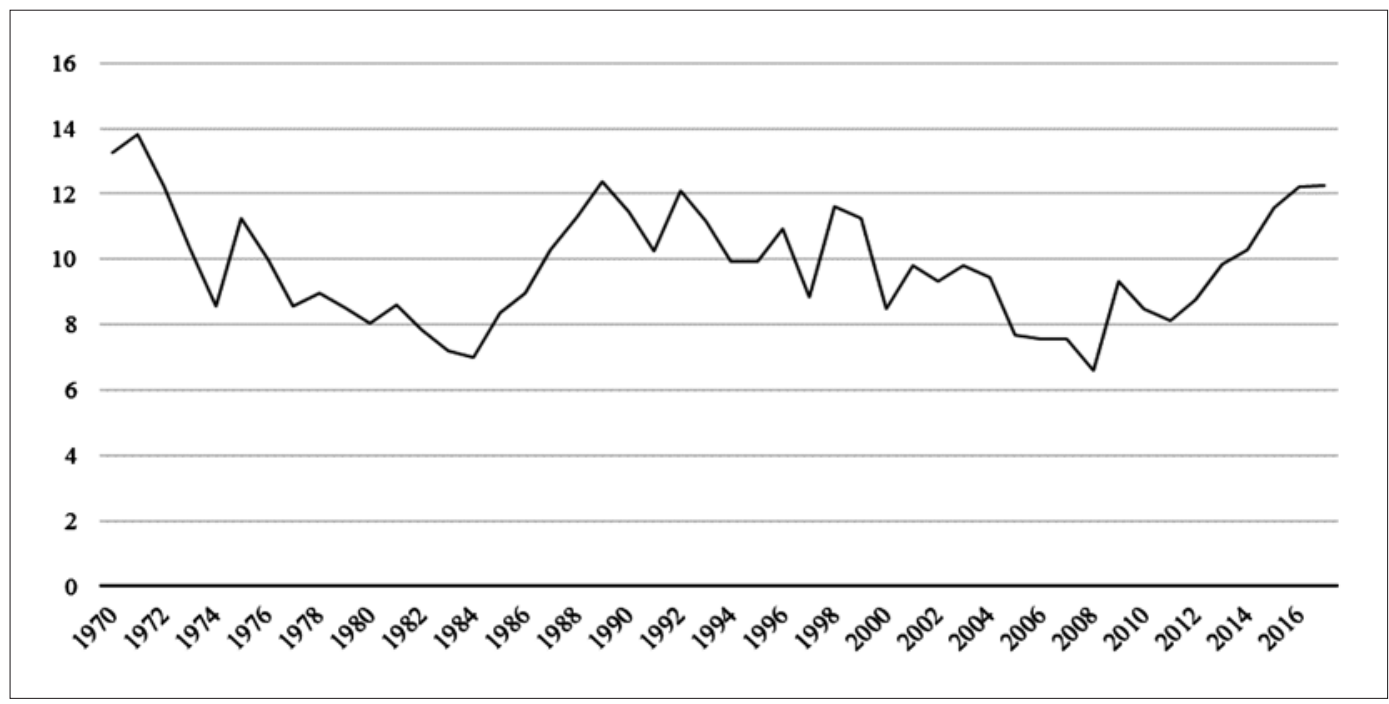

ed of agriculture in the GDP displays no trend (Figure 2). Nevertheless, the contribution of the agricultural sector shows a net decline in the socialist regime environment (until 1984), a net increase in the beginning of the transitional regime (1984 to 1991), another decline until 2008 (where Algeria spent the highly unstable political decade and its consequences), and recently the agricultural sector regain its importance with increasing share.

Therefore, with this sketch in mind, the agricultural supply response in Algeria, since the independence (1962) until now, has been limited mainly by structural and institutional constraints that have persisted despite the many reforms (as well climatic factors are also crucial determinants of the supply). ${ }^{2}$ The study of Ghafouri (1988) should by highlighted here. His study covers twelve-year period (1972-84) and applying the Nerlovian model on four agricultural products, namely: citrus, grapes, cereal production and gardening products. His empirical results were unsatisfactory, in his words "not even worthy to report". Ghafouri's study concluded firmly that Algerian farmers do not respond rationally to economic incentives (mainly prices). He explains this by the fact that farmers in that period subsist in a socialist sector completely centralized which prevent the freedom of choices. The implication from this experience is that the underlying model is not an adequate one for the context of developing countries. To understand the Nerlovian model and its underlying hypotheses, a brief sketch on the theory of supply response would be helpful.

One of the basics of economic theory states that there is a positive relationship between the price and the quantity supplied, and implying that farmers respond equally to price changes. The existence of this positive relationship is based on the well-established behavioral assumption of profit maximization of economic agents. In order to confirm that, agricultural supply response studies widely use the Nerlovian model that has been applied in most developed and developing countries. ${ }^{3}$ This model, called

\footnotetext{
2 Whereas, this aspect is not included in this study. See Bozzola et al., 2018; Migliore et al., 2019 and Chavas et al., 2019 for the Mediterranean context.

${ }^{3}$ For a critical review in LDCs, see: Binswanger, 1989; Schiff \& Montenegro, 1997; Ozanne, 1999; Thiele, 2000 and Kumar, 2017.
} 
the partial adjustment model, could be written under a simple specification as follows:

$$
Q_{t}=\beta_{0}+\beta_{1} P_{t-1}+\beta_{2} Q_{t-1}+\beta_{3} Z_{t}
$$

where $Q$ stands for agricultural output, $P$ for price, $Z$ for other factors. The subscript $t$ for current period and $t-1$ for the previous period. As the variables are taken in logarithms, the estimated coefficients, $\beta_{i}$ are interpreted as elasticities. Particularly, $\beta_{1}$ as the short-run elasticity, and $\beta_{I} /\left(1-\beta_{2}\right)$ as the long-run elasticity. This model is estimated from variables measured in levels by an OLS estimation with non-stationary data which yields spurious regressions (Granger \& Newbold, 1974; Johansen, 1988). Therefore, the results yielded a conflicting evidence ranging from perverse effects to low price elasticity to lack of responsiveness at all, depending on the country, region, crop and aggregation level.

This study is motivated by using more elaborated model of supply response estimation in order to test a general hypothesis as raised by Thiele (2000) from the study of Krueger et al. (1992) which stipulates that: appropriate (direct and indirect) price incentives alone encourage agricultural development. Moreover, this study uses a commodity level analysis which gained more emphasis instead of more aggregated measures incorporating change in total agricultural output at country level, or even global such as Hendricks et al. (2018), which are less frequently seen in the empirical literature (Ozkan et al., 2011). Besides the fact that aggregate models are superior to the micro-model in predicting acreage response (Wu \& Adams, 2002).

\section{Research methodology}

\subsection{Data source and crops choice}

The used data was obtained fully from the Food and Agriculture Organization's statistical database (FAO) ${ }^{4}$ Two variables of interest were selected for the subject of this study: cropped area $^{5}$ and crop price. The area is measured by 1000 hectares and producer prices in $10000 \mathrm{LCU}$ per ton for the easiness seek. The data were converted to logarithms in order to easily interpret coefficients of interest as elasticities. Hence, the database has a time series structure, which for both variables, begins in 1966 and ends in 2018 .

The procedure of crops selection is as follows: all data on crop areas were selected on the FAO database (167 crops). The results show that only 56 crops were available for Algeria. From this crops set, only 44 crops have the corresponding prices (annual producer prices). In order to maintain only the full-length time or at least recent records, it was found that 22 crops have historical data, i.e., series interrupted in the $90 \mathrm{~s}$ (typically: 1966-1990, 1966-1995, etc.). In the remaining 22 crops, the three existing cereals (wheat, barley and oat) were dismissed from the set due to certain considerations of direct price intervention policy envisaged by the Algerian government. As a result, we get the final database of 19 crops including 8 fruits (apple, date, grape, lemon, mandarin, melon, orange and pear) and 9 vegetables (carrot, cauliflower, chili pepper, garlic, bulb onion, scallion, potato, pumpkin and tomato) and 2 pulses (green bean and pea). Table 1 represents the per mille shares of each selected crop in the total cropland area in the corresponding three years (1966, 2002 and 2018), along with the time intervals.

Table 1 shows the relative importance of the selected crops with respect to the year-corresponding cropland area in Algerian agriculture. All crops show an increasing importance, except for grape and mandarin, and for some extent orange crops. More particularly, grape was the only major crop in Algerian agriculture, whereas its importance has been declined gradually (from 49.41\% in 1966 to $8.19 \%$ in 2018). Moreover, most recently (in 2018) and due to the changes in food consumption pattern of Algerian population, it seems that date and potato crops are the most important crops in

\footnotetext{
4 FAO official website: http://www.fao.org/faostat/en/\#data.

5 As initiated by Nerlove $(1956 ; 1958)$, the traditional approach to supply response for individual agricultural commodities involves the use of planted or harvested acreage to represent planned output (Seale et al., 2013).
} 
Table 1 - The shares of cropland area for each selected crop.

\begin{tabular}{|c|c|c|c|c|}
\hline \multirow{2}{*}{ Crops } & \multirow{2}{*}{ Time Interval } & \multicolumn{3}{|c|}{ Shares (\%o) in the total cropland area } \\
\hline & & 1966 & 2002 & 2018 \\
\hline Apple & $1966-2018$ & 0.36 & 1.85 & 4.60 \\
\hline Date & $1966-2018$ & 6.78 & 14.72 & 19.93 \\
\hline Grape & $1966-2018$ & 49.41 & 6.60 & 8.19 \\
\hline Lemon & $1966-2018$ & 0.22 & 0.34 & 0.53 \\
\hline Mandarin & $1966-2018$ & 2.06 & 1.49 & 1.83 \\
\hline Melon & $1966-2018$ & 2.54 & 3.55 & 7.13 \\
\hline Orange & $1966-2018$ & 6.19 & 3.43 & 6.00 \\
\hline Pear & $1966-2018$ & 0.28 & 1.45 & 2.66 \\
\hline Bean & $1966-2018$ & 0.23 & 0.78 & 1.37 \\
\hline Carrot & $1966-2018$ & 0.59 & 2.47 & 2.11 \\
\hline Cauliflower & 2001-2018 & l & 0.47 & 0.95 \\
\hline Chili Pepper & $2002-2018$ & l & 1.99 & 2.61 \\
\hline Garlic & $1987-2018$ & 1 & 1.09 & 1.52 \\
\hline Onion (bulb) & $1966-2018$ & 1.04 & 3.61 & 5.58 \\
\hline Onion (Scallion) & $1995-2018$ & 1 & 0.03 & 0.04 \\
\hline Pea & $1966-2018$ & 0.61 & 0.86 & 1.22 \\
\hline Potato & $1966-2018$ & 3.75 & 8.84 & 17.67 \\
\hline Pumpkin & $2002-2018$ & 1 & 0.99 & 1.59 \\
\hline Tomato & $1966-2018$ & 1.08 & 2.17 & 2.63 \\
\hline
\end{tabular}

Algeria (with shares of $19.93 \%$ and $17.67 \%$ respectively). In general, all crops display a significant relative importance in Algerian farming system. In terms of the time interval, almost all crops have a full-length interval (i.e., 52 years), which is a very long time length for any analysis, except for cauliflower, chili, garlic, scallion and pumpkin, representing shorter time lengths (from 16 to 31 years), which is also long enough.

\subsection{Estimation method: The ECM approach to supply response}

The Nerlovian partial adjustment model has been the dominant method used in modeling the supply response during the last decades of the $20^{\text {th }}$ century. It was based on the minimization of a single period loss function $L$ of the form: $L_{t}=\lambda_{1}\left(Y_{t}-Y_{t}^{*}\right)^{2}+\lambda_{2}\left(Y_{t}-Y_{t-1}^{*}\right)^{2}$ for a given level of a variable, $Y$. The results yield the partial adjustment model with a coefficient of adjustment $\lambda=\lambda_{1} / \lambda_{2}$. The model assumes that there is an equilibrium toward which producers are moving in the long-run and determined on the basis of a static theory of optimization (static expectations), ${ }^{6}$ which assumes that future values of the exogenous variables (mainly prices) remain unchanged (Weliwita \& Govindasamy, 1997). By using a more general intertemporal quadratic loss function, Nichell (1985), Hallam \& Zano-

${ }^{6}$ As criticized by Nerlove himself (1958; 1979). For a detailed review, see: Askari \& Cummings, 1977, chapter 4; Hallam \& Zanoli, 1993 and more recently Seale et al. (2013). 
li (1993) and Johansen (1988; 1995) developed more realistic and dynamical adjustment model, which results in the use of "the Error Correction Model". Therefore, the Error Correction Model has become a more general approach to modeling agricultural supply response than the commonly used Nerlove partial adjustment model, particularly the last two decades.

The modeling procedure begins with establishing the long-run equilibrium relationship between $y$ (cropped area as a proxy of the agricultural output) and $x$ (producer price) as expressed by the following formula:

$$
y_{t}=\beta x_{t}+\varepsilon_{t}
$$

Thus, the simplest form of the error correction model can be written as following:

$$
\Delta y_{t}=\delta \Delta x_{t}-\lambda \varepsilon_{t-1}+\omega_{t}
$$

where $\omega_{t}$ is a disturbance with mean zero, constant variance, and zero covariance. $\delta$ measures the short-run effect on $y$ of changes in $x$. $\varepsilon_{t-1}$ measures the errors which corresponds to the residuals of a lagged version of long-run equilibrium relationship (equation [1]). $\lambda$ measures the extent of correction of these errors by adjustments in $y$, the negative sign showing that adjustments are made towards restoring the long-run relationship, and the short-run adjustments are therefore guided by, and consistent with, the long-run equilibrium relationship (Hallam \& Zanoli, 1993). For the correctness of the ECM procedure, values of $\lambda$ should be negative, between 0 and 1, and also statistically significant. The ECM approach can be interpreted as describing farmers reacting to moving targets and optimizing their objective function under dynamic conditions (McKay et al., 1999; Olubode-Awosola et al., 2006). Before running the modeling procedure, a cointegration analysis should be performed according to the "Granger representation theorem". This theorem points out that where variables are cointegrated, I (1), there exists a valid Error Correction Model describing their relationship (Engle \& Granger, 1987; Apostolopoulos \& Stoforos, 1995), with the implication that co-integration between the variables involved is a prerequisite for the Error Correction Model (Hallam \& Zanoli, 1993; Seale et al., 2013).

\section{Results and discussion}

This section presents the findings on the aggregate supply response patterns in Algeria, showing the responsiveness of the selected crops to varying changes in the prices changes covering mostly the period from 1966 to 2018 . Therefore, the section contains empirical results of cointegration analysis that addresses the patterns of supply and main estimation results of 38 regressions for the supply functions of the selected crops.

Results of the Augmented Dickey-Fuller (ADF) and cointegration analysis are shown in Table 2. The first column represents the selected crops. In order to test for non-stationarity of economic series included in regression models as to avoid the spurious regressions, this study conducted the ADF unit root tests of each variable in the study. The test was performed on the levels with constant (without trend term) using 4 lag order and $t$-statistic criterion. The results are summarized in column 2 for both areas ( $y$ ) and prices $(x)$ for each crop. Values in parentheses represent their respective $t$-ratios. Essentially all the series in cropped areas and crop prices were associated with $t$ statistic that is greater than the critical value for the rejection of unit root for each ADF test. Thus, the series are not stationary, i.e., the null hypothesis of non-stationarity for the 38 variables was accepted. The significant and important evidence from the ADF unit root tests relates to the presence of non-stationary series in both area and price variables for the 19 crops.

For any meaningful long-run relationship to exist between the two non-stationary series (areas and prices), it is imperative that some linear combinations of the series must be co-integrated. More particularly, they must follow a common trend which permits a stable long-run relationship for both. If cointegration is statistically confirmed, a non-spurious long-run equilibrium relationship exists. Thus, this study conducted both Engle-Granger and Johansen cointegration 
Table 2 - The ADF and cointegration tests for the selected crops in Algerian agriculture.

\begin{tabular}{|c|c|c|c|c|c|}
\hline \multirow{2}{*}{ Crops } & \multirow{2}{*}{$\begin{array}{c}\text { Augmented } \\
\text { DF Test }\end{array}$} & \multirow{2}{*}{$\begin{array}{c}\text { Engle-Granger } \\
\text { Test } \\
\end{array}$} & \multicolumn{3}{|c|}{ Johansen Test } \\
\hline & & & \multicolumn{2}{|c|}{ Eigenvalue Test } & Trace Test \\
\hline \multicolumn{6}{|l|}{ Fruits } \\
\hline Apple & $\begin{array}{ll}y & -0.136(-2.14) \\
x & -0.012(-1.09)\end{array}$ & $-0.164(-2.32)$ & & $\begin{array}{l}0.236 \\
0.003\end{array}$ & $\begin{array}{ll}14.222 & (0.022) \\
0.187 & (0.736)\end{array}$ \\
\hline Date & $\begin{array}{ll}\mathrm{y} & -0.137(-2.01) \\
x & -0.136(-3.27)\end{array}$ & $-0.086(-1.50)$ & & $\begin{array}{l}0.411 \\
0.001\end{array}$ & $\begin{array}{ll}27.574 & (0.003) \\
0.0014 & (0.969)\end{array}$ \\
\hline Grape & 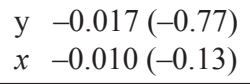 & $-0.065(-2.14)$ & $\begin{array}{l}0 \\
1\end{array}$ & $\begin{array}{l}0.386 \\
0.004\end{array}$ & $\begin{array}{ll}25.442 & (0.009) \\
0.022 & (0.880)\end{array}$ \\
\hline Lemon & $\begin{array}{ll}y & -0.138 \\
x & -0.226(-2.41) \\
\end{array}$ & $-0.146(-1.80)$ & & $\begin{array}{l}0.136 \\
0.053\end{array}$ & $\begin{array}{l}10.475(0.250) \\
2.8521(0.091)\end{array}$ \\
\hline Mandarin & 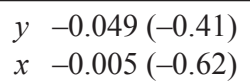 & $-0.104(-1.19)$ & & $\begin{array}{l}0.261 \\
0.052\end{array}$ & $\begin{array}{l}18.605(0.015) \\
2.8132(0.093)\end{array}$ \\
\hline Melon & $\begin{array}{ll}y & -0.142(-1.78) \\
x & -0.145(-2.14)\end{array}$ & $-0.148(-2.06)$ & & $\begin{array}{l}0.134 \\
0.001\end{array}$ & $\begin{array}{ll}7.584 & (0.517) \\
0.060 & (0.805)\end{array}$ \\
\hline Orange & $\begin{array}{ll}y & -0.015(-0.36) \\
x & -0.010(-0.16)\end{array}$ & $-0.044(-1.10)$ & $\begin{array}{l}0 \\
1\end{array}$ & $\begin{array}{l}0.090 \\
0.001\end{array}$ & $\begin{array}{ll}5.056 & (0.801) \\
0.095 & (0.757) \\
\end{array}$ \\
\hline Pear & $\begin{array}{ll}y & -0.172(-2.28) \\
x & -0.008(-0.55)\end{array}$ & $-0.158(-1.54)$ & & $\begin{array}{l}0.112 \\
0.003\end{array}$ & $\begin{array}{ll}6.197 & (0.676) \\
0.003 & (0.951) \\
\end{array}$ \\
\hline \multicolumn{6}{|c|}{ Vegetables and pulses } \\
\hline Bean & $\begin{array}{ll}\mathrm{y} & -0.104(-1.09) \\
\mathrm{x} & -0.031(-0.96)\end{array}$ & $-0.267(-3.04)$ & $\begin{array}{l}0 \\
1 \\
\end{array}$ & $\begin{array}{l}0.292 \\
0.066\end{array}$ & $\begin{array}{ll}21.555 & (0.004) \\
3.595 & (0.057) \\
\end{array}$ \\
\hline Carrot & $\begin{array}{ll}\mathrm{y} & -0.139(-1.60) \\
\mathrm{x} & -0.087(-1.20)\end{array}$ & $-0.084(-1.36)$ & $\begin{array}{l}0 \\
1\end{array}$ & $\begin{array}{l}0.094 \\
0.014\end{array}$ & $\begin{array}{ll}5.953 & (0.703) \\
0.770 & (0.380)\end{array}$ \\
\hline Cauliflower & $\begin{array}{ll}\mathrm{y} & -0.971(-1.81) \\
\mathrm{x} & -1.299(-2.34)\end{array}$ & $-0.827(-3.41)$ & $\begin{array}{l}0 \\
1\end{array}$ & $\begin{array}{l}0.443 \\
0.005\end{array}$ & $\begin{array}{ll}9.971 & (0.288) \\
0.005 & (0.982)\end{array}$ \\
\hline Chili Pepper & $\begin{array}{ll}\mathrm{y} & -0.435(-2.59) \\
\mathrm{x} & -0.382(-1.58)\end{array}$ & $-0.609(-3.13)$ & $\begin{array}{l}0 \\
1\end{array}$ & $\begin{array}{l}0.567 \\
0.153\end{array}$ & $\begin{array}{ll}16.096 & (0.038) \\
2.670 & (0.102)\end{array}$ \\
\hline Garlic & 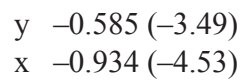 & $-0.294(-2.06)$ & $\begin{array}{l}0 \\
1\end{array}$ & $\begin{array}{l}0.194 \\
0.006\end{array}$ & $\begin{array}{ll}6.710 & (0.617) \\
0.019 & (0.887)\end{array}$ \\
\hline Onion (bulb) & $\begin{array}{ll}\mathrm{y} & -0.245(-2.78) \\
\mathrm{x} & -0.297(-2.38)\end{array}$ & $-0.393(-2.79)$ & $\begin{array}{l}0 \\
1\end{array}$ & $\begin{array}{l}0.305 \\
0.001\end{array}$ & $\begin{array}{ll}18.977 & (0.012) \\
0.001 & (0.991)\end{array}$ \\
\hline Onion (Scallion) & $\begin{array}{ll}\mathrm{y} & -0.381(-2.14) \\
\mathrm{x} & -0.709(-1.52)\end{array}$ & $-0.666(-3.36)$ & $\begin{array}{l}0 \\
1\end{array}$ & $\begin{array}{l}0.396 \\
0.040\end{array}$ & $\begin{array}{ll}12.561 & (0.132) \\
0.944 & (0.331) \\
\end{array}$ \\
\hline Pea & $\begin{array}{ll}\mathrm{y} & -0.167(-2.10) \\
\mathrm{x} & -0.100(-1.53)\end{array}$ & $-0.383(-3.48)$ & $\begin{array}{l}0 \\
1\end{array}$ & $\begin{array}{l}0.211 \\
0.003 \\
\end{array}$ & $\begin{array}{ll}12.539 & (0.133) \\
0.205 & (0.650) \\
\end{array}$ \\
\hline Potato & $\begin{array}{ll}\mathrm{y} & -0.125(-1.82) \\
\mathrm{x} & -0.130(-1.27)\end{array}$ & $-0.237(-2.82)$ & $\begin{array}{l}0 \\
1\end{array}$ & $\begin{array}{l}0.153 \\
0.002 \\
\end{array}$ & $\begin{array}{ll}8.690 & (0.401) \\
0.013 & (0.907) \\
\end{array}$ \\
\hline Pumpkin & $\begin{array}{ll}\mathrm{y} & -0.671(-1.01) \\
\mathrm{x} & -0.984(-3.48)\end{array}$ & $-0.656(-3.01)$ & $\begin{array}{l}0 \\
1\end{array}$ & $\begin{array}{l}0.404 \\
0.109\end{array}$ & $\begin{array}{ll}10.166 & (0.273) \\
1.861 & (0.172)\end{array}$ \\
\hline Tomato & $\begin{array}{ll}\mathrm{y} & -0.182(-2.30) \\
\mathrm{x} & -0.010(-0.15)\end{array}$ & $-0.194(-2.57)$ & $\begin{array}{l}0 \\
1\end{array}$ & $\begin{array}{l}0.118 \\
0.003\end{array}$ & $\begin{array}{ll}6.739 & (0.613) \\
0.159 & (0.689)\end{array}$ \\
\hline
\end{tabular}

Note: Values in parentheses are: for the ADF and Engle-Granger tests, represent the t-statistic, and for the Johansen test, they represent the p-values for the test. 
tests for the linear combination of the series for the selected crops. The Engle-Granger is known as a residual-based single-equation approach. It assumes that the variables in the long-run equation are all I(1) and tests whether the error term in equation [1] is I(1) against the alternative that it is $\mathrm{I}(0)$. Whereas the Johansen reduced-rank approach is a system approach which tests for the existence of a more than one co-integrating relationship using both the Eigenvalue and Trace tests. The two procedures are used together in this study only to support evidence on the longrun equilibrium relationships among variables. The results are summarized in columns 3 and 4 of the Table 2. According to these tests results, both the Engle-Granger and the Johansen tests indicate the existence of co-integrating relationships between planned supply (cropped area) and the price variables.

After long-run relationships between cropped area and the price variables predicting it are confirmed, the ECM could be established. Results are reported in Table 3. The first column represents the selected crops. The long-run regressions results are performed separately and only the values of $\beta$ were reported in the second columns. The 19 regressions present typically (although necessarily) higher values of $R^{2}$ with the presence of autocorrelation (i.e. low values of $D W$ statistic). The remained columns display the results of 19 ECM estimations. The models are evaluated on the basis of the following criteria: adjusted coefficient of determination $\left(\hat{R}^{2}\right)$, Durbin-Watson statistic $(D W)$ and the $F$-statistic for the overall statistical significance. The last column represents the time length (T) until 2018.

According to results from the long-run estimates ( $\beta$ estimates), planned supply of most selected crops are affected positively (with higher statistical significance at $1 \%$ ) by their own prices. Except for grape, mandarin and orange fruits which display significant negative effects. These findings revealed that the lagged price of most crops had a positive influence on the current crop production. This indicated that the Algerian farmers in general responded positively (i.e. rationally) to the previous year's price to determine the future drift in price. It is noteworthy to mention that among fruit producers, apple growers have the highest long-run elasticities $(51.1 \%)$. Whereas among vegetable producers, it seems that cauliflower, chili pepper and scallion growers have the highest long-run elasticities (99.2, 56.5 and $63.9 \%$ respectively).

The short-run relationship estimation is less worth diagnosing, besides having a low goodness of fit. The short-run elasticities ( $\delta$ estimates) of most of crops are low with relatively low statistical significance. Except for bulb onion (at 1\%), bean, chili, pumpkin crops (at 5\%) and grape and cauliflower crops (at 10\%). However, the most interesting idea in the interpretation of the results of the ECM is to check the EC term ( $\lambda$ estimates) conditions: its negative value, its absolute value, and its significance. It seems from the coefficient estimates of $\lambda$ that all values are negative, statistically significant and its values are between 0 and 1 . The error correction coefficient indicates a differential feedback of the previous year's disequilibrium from the long-run elasticity of crops price. This implies that the speed with which crops price adjust from the short-run disequilibrium to changes in crop supply in order to attain the long-run equilibrium within one year differs significantly from crop to another. More particularly date, bean, cauliflower, chili and pumpkin crops are the most rapid adjustment rates among all selected crops (respectively $43,47,51,58$ and $66.5 \%$ for each year). Conversely, grape and orange crops have the lowest rates of price adjustment (respectively 1.6 and $1.3 \%$ each year). Curiously, these two fruit crops exhibit abnormal behavior in the long-run price response. ${ }^{7}$ The remained fruits have rates between 1 and $24 \%$, while the other vegetables are between 12 and $29 \%$. Nonetheless, these further confirm once again, the existence of the cointegration relationship in the models.

\footnotetext{
7 This abnormal behavior perhaps could be due to a misspecification in the long-run supply function, to the extent that these crops have been submitted to some technological advances or intense supply shifts induced on stable demand curves, as they are considered as industrial inputs par excellence.
} 
Table 3 - The ECM results (long- and short-run) for the selected crops in Algerian agriculture, 1966-2018.

\begin{tabular}{|c|c|c|c|c|c|c|c|}
\hline Crops & $\beta$ & $\delta$ & $\lambda$ & $\hat{R}^{2}$ & $D W$ & $F$ & $T$ \\
\hline \multicolumn{8}{|l|}{ Fruits } \\
\hline Apple & $\begin{array}{l}0.511 \\
(24.13)^{* * *}\end{array}$ & $\begin{array}{l}0.192 \\
(1.64)\end{array}$ & $\begin{array}{l}-0.157 \\
(-2.22)^{* *}\end{array}$ & 0.135 & 1.853 & $3.90 * *$ & 52 \\
\hline Date & $\begin{array}{l}0.199 \\
(20.16)^{* * *}\end{array}$ & $\begin{array}{l}0.078 \\
(0.81)\end{array}$ & $\begin{array}{l}-0.428 \\
(-3.75)^{* * *}\end{array}$ & 0.230 & 1.993 & $7.48 * * *$ & 52 \\
\hline Grape & $\begin{array}{l}-0.241 \\
(-16.27)^{* * *}\end{array}$ & $\begin{array}{l}-0.089 \\
(-2.00)^{*}\end{array}$ & $\begin{array}{l}-0.016 \\
(-3.54)^{* * *}\end{array}$ & 0.103 & 1.337 & $2.75^{*}$ & 52 \\
\hline Lemon & $\begin{array}{l}0.227 \\
(12.99)^{* * *}\end{array}$ & $\begin{array}{l}0.046 \\
(0.65)\end{array}$ & $\begin{array}{l}-0.160 \\
(-2.56)^{* *}\end{array}$ & 0.155 & 2.059 & $3.64 * *$ & 52 \\
\hline Mandarin & $\begin{array}{l}-0.029 \\
(-4.11)^{* * *}\end{array}$ & $\begin{array}{l}-0.013 \\
(-0.19)\end{array}$ & $\begin{array}{l}-0.247 \\
(-2.24)^{* *}\end{array}$ & 0.101 & 2.373 & $2.56 * *$ & 52 \\
\hline Melon & $\begin{array}{l}0.171 \\
(12.81)^{* * *}\end{array}$ & $\begin{array}{l}0.093 \\
(1.55) \\
\end{array}$ & $\begin{array}{l}-0.155 \\
(-2.22)^{* *}\end{array}$ & 0.116 & 1.979 & $4.49 * *$ & 52 \\
\hline Orange & $\begin{array}{l}-0.267 \\
(-3.25)^{* * *}\end{array}$ & $\begin{array}{l}0.010 \\
(0.24)\end{array}$ & $\begin{array}{l}-0.013 \\
(-1.97)^{* *}\end{array}$ & 0.102 & 1.677 & $1.15^{*}$ & 52 \\
\hline Pear & $\begin{array}{l}0.438 \\
(23.96)^{* * *}\end{array}$ & $\begin{array}{l}0.135 \\
(1.59) \\
\end{array}$ & $\begin{array}{l}-0.193 \\
(-2.50)^{* *}\end{array}$ & 0.145 & 1.829 & $4.25 * *$ & 52 \\
\hline \multicolumn{8}{|c|}{ Vegetables and pulses } \\
\hline Bean & $\begin{array}{l}0.301 \\
(31.87)^{* * *}\end{array}$ & $\begin{array}{l}0.182 \\
(2.11)^{* *}\end{array}$ & $\begin{array}{l}-0.479 \\
(-4.46)^{* * *}\end{array}$ & 0.316 & 1.734 & $11.58 * * *$ & 52 \\
\hline Carrot & $\begin{array}{l}0.414 \\
(8.07)^{* * *}\end{array}$ & $\begin{array}{l}0.187 \\
(1.21)\end{array}$ & $\begin{array}{l}-0.192 \\
(-1.94)^{*}\end{array}$ & 0.146 & 2.179 & 1.29 & 52 \\
\hline Cauliflower & $\begin{array}{l}0.992 \\
(8.67)^{* * * *}\end{array}$ & $\begin{array}{l}0.393 \\
(2.00)^{*}\end{array}$ & $\begin{array}{l}-0.506 \\
(-2.26)^{* *}\end{array}$ & 0.284 & 1.911 & $2.98 * *$ & 17 \\
\hline Chili Pepper & $\begin{array}{l}0.565 \\
(6.80)^{* * *}\end{array}$ & $\begin{array}{l}0.353 \\
(2.38)^{* *}\end{array}$ & $\begin{array}{l}-0.580 \\
(-3.10)^{* * *}\end{array}$ & 0.502 & 1.593 & $7.06^{* * *}$ & 16 \\
\hline Garlic & $\begin{array}{l}0.105 \\
(5.21)^{* * *}\end{array}$ & $\begin{array}{l}-0.007 \\
(-0.165)\end{array}$ & $\begin{array}{l}-0.296 \\
(-2.30)^{* *}\end{array}$ & 0.173 & 1.399 & $2.83^{*}$ & 31 \\
\hline Onion (bulb) & $\begin{array}{l}0.338 \\
(3.75)^{* * *}\end{array}$ & $\begin{array}{l}0.161 \\
(3.10)^{* * *}\end{array}$ & $\begin{array}{l}-0.269 \\
(-2.78) * * *\end{array}$ & 0.223 & 2.161 & $7.20 * * *$ & 52 \\
\hline Onion (Scallion) & $\begin{array}{l}0.639 \\
(3.34)^{* * *}\end{array}$ & $\begin{array}{l}0.057 \\
(1.64)\end{array}$ & $\begin{array}{l}-0.244 \\
(-4.74)^{* * *}\end{array}$ & 0.133 & 1.185 & 1.61 & 23 \\
\hline Pea & $\begin{array}{l}0.323 \\
(3.34)^{* * *}\end{array}$ & $\begin{array}{l}-0.052 \\
(-0.33)\end{array}$ & $\begin{array}{l}-0.198 \\
(-2.30)^{* * *}\end{array}$ & 0.102 & 2.037 & $2.86^{*}$ & 52 \\
\hline Potato & $\begin{array}{l}0.183 \\
(8.13)^{* * *}\end{array}$ & $\begin{array}{l}-0.016 \\
(-0.24) \\
\end{array}$ & $\begin{array}{l}-0.146 \\
(-2.41)^{* *}\end{array}$ & 0.113 & 1.727 & $3.19^{*}$ & 52 \\
\hline Pumpkin & $\begin{array}{l}0.340 \\
(6.83)^{* * *}\end{array}$ & $\begin{array}{l}0.218 \\
(2.64)^{* *}\end{array}$ & $\begin{array}{l}-0.665 \\
(-2.81)^{* *}\end{array}$ & 0.437 & 2.072 & $5.44^{*}$ & 16 \\
\hline Tomato & $\begin{array}{l}0.065 \\
(1.99)^{*}\end{array}$ & $\begin{array}{l}-0.190 \\
(-1.36)\end{array}$ & $\begin{array}{l}-0.125 \\
(-1.97)^{*}\end{array}$ & 0.133 & 2.195 & $3.84 *$ & 52 \\
\hline
\end{tabular}

Note: Values in parentheses represent the t-statistic. *** for significance at $1 \%$, ** for significance at 5\%, * for significance at 10\%, no asterisks for no significance at all. 
In terms of the sign of long- and short-run elasticities for selected crops of this study, the findings corroborate many results of recent studies. Nevertheless, some of them used slightly different methodologies. However, the common point is the acreage responsiveness to crop prices. Studies with positive response elasticities are as follows: Haiyan \& Xuezhong (2017) for apples in China; Wani et al. (2015) for apples and pears in Jammu \& Kashmir; Gurikar (2011) for onions in India; Seale et al. (2013) for oranges, tomatoes and bulb onion in the U.S.; $\mathrm{Xu}$ et al. (2012) for grapes in China; Mostofa et al. (2010) for cauliflower and tomato in Bangladesh; Yao \& Zhou (2013) for garlic in China; Vembu et al. (2013) and Abraham \& Pingali (2019) for several pulses in India; Huq \& Arshad (2010) for potato in Bangladesh; Lantican et al. (2008) for tomato in Philippines.

\section{Conclusion}

The paper examined agricultural supply response for Algerian agriculture. Data was taken for the period 1966 to 2018 provided by the FAO statistical database on cropped areas and crop prices, where 19 crops were minutely selected. The paper aimed to investigate the extent that Algerian farmers do respond to economic incentives. Time series analytic techniques (cointegration analysis and Error Correction Model) were used to undermine the quantitative effects of the price of the selected crops production.

The main findings of this study could be summarized as follows. The selected variables were non-stationary (as confirmed by the ADF unit root tests). The bivariate analysis of these two variables (using both Engle-Granger and Johansen procedures) for each crop confirmed the existence of co-integrating relationships between them. The study also indicated that the long-run elasticities with respect to prices are generally low and statistically significant, and the results of the ECM confirmed the positive responsiveness to prices with differential rates of adjustment for all selected crops.

Some useful implications could be derived from this study. As the estimated supply elasticities came out to be less than unity, this means that supply response is price inelastic, whereas they appeared to be high enough to imply that further agricultural reforms are required. Furthermore, to the extent that the aggregate supply of these crops is positively affected by its own producer prices in both the short-run and long-run as established econometrically, these findings rule out the applicability of perverse supply response in Algerian agriculture. Moreover, the findings suggest that farmers tend to increase acreage cultivated in response to economic incentives (namely prices). This implies that farmers have (or at least began to have) more control over land than the other factors that could influence agricultural output. Also, the analysis showed that short-run response in crop production is lower than long-run response. This is because in the short run the farmers are constrained by the access to resources needed to adjust appropriately to economic incentives. In the short-run, inputs are considered as relatively fixed. To address these concerns government should devise policies to make land available to farmers so that prospective farmers could increase acreage cultivated. The findings also suggest that farmers are indeed responsive, which is consistent with the evidence of the positive effects of the pricing policies, launched since the adjustment policies were inaugurated in the $1990 \mathrm{~s}$, on the producer's behavior in terms of production choices and performance.

This study pave the path for several research perspectives on the performance of agricultural supply in Algeria despite certain limitations. In our analysis, non-price factors were not considered for the sake of simplicity, despite their crucial importance. Further studies could include those already available, including mainly the effect of the technology level, effect of irrigation facilities, effect of production risks on producers' choices, and even the instability of political regimes in the agricultural sector. Although our analysis has the advantage of being based on a very long time interval (52 years), a sequential analysis on specific and more homogeneous periods could be conducted for each crop separately, especially for the fruit crops that revealed problems of perversity (mainly grape and orange crops). This would be a prosperous task that could provide valuable 
information in terms of the implementation of adequate incentive structures. However, more indepth research on the agricultural supply response in Algeria is needed in order to contribute in the design of pricing policies aimed at fostering the growth of the agricultural sector.

\section{References}

Abraham M., Pingali P., 2019. Shortage of Pulses in India: Understanding How Markets Incentivize Supply Response. Journal of Agribusiness in Developing and Emerging Economies, forthcoming.

Apostolopoulos C.D., Stoforos C.E., 1995. Alternative Dynamics in Agricultural Supply Response. Medit, 6(2): 49-54.

Askari H., Cummings J.T., 1977. Agricultural Supply Response. A Survey of the Econometric Evidence. New York: Praeger Publishers.

Binswanger H., 1989. The Policy Response of Agriculture. The World Bank Economic Review, 3(1): 231-258.

Bozzola M., Massetti E., Mendelsohn R., Capitanio F., 2018. A Ricardian Analysis of the Impact of Climate Change on Italian Agriculture. European Review of Agricultural Economics, 45(1): 57-79.

Chavas J.P., Di Falco S., Adinolfi F., Capitanio F., 2019. Weather Effects and their Long-Term Impact on the Distribution of Agricultural Yields: Evidence from Italy. European Review of Agricultural Economics, 46(1): 29-51.

Engle R.F., Granger C.W.J., 1987. Cointegration and Error Correction: Representation, Estimation and Testing. Econometrica, 55(2): 251-276.

Ghafouri A., 1988. Supply Response in the Algerian Agriculture. Dissertation, University of Leicester, UK.

Granger C.W.J., Newbold P., 1974. Spurious Regressions in Econometrics. Journal of Econometrics, 2(2): 111-120.

Gurikar R.Y., 2011. Supply Response of Onion in Karnataka State: An Econometric Analysis. Dissertation. University of Agricultural Sciences, Dharwad, India.

Haiyan Z., Xuezhong L., 2017. Research on Supply Response of Apple in China. Forestry Economics, 9: 21 .

Hallam D., Zanoli R., 1993. Error Correction Models and Agricultural Supply Response. European Review of Agricultural Economics, 20(2): 151-166.

Hendricks N.P., Smith A.D., Villoria N.B., 2018. Global Agricultural Supply Response to Persistent
Price Shocks. Annual Meeting of Agricultural \& Applied Economics Association, Washington, D.C. Huq A.S.M.A., Arshad F.M., 2010. Supply Response of Potato in Bangladesh: A Vector Error Correction Approach. Journal of Applied Sciences, 10(11): 895-902.

Johansen S., 1988. Statistical Analysis of Cointegration Vectors. Journal of Economic Dynamics and Control, 12(2-3): 231-254.

Johansen S., 1995. Likelihood-Based Inference in Cointegrated Vector Autoregressive Models. New York: Oxford University Press.

Krueger A.O., Schiff M., Valdes A., 1992. The Political Economy of Agricultural Pricing Policies: A World Bank Comparative Study. Baltimore: Johns Hopkins University Press.

Kumar P., 2017. Supply Response Function in Indian Agriculture. In: Changing Contours of Indian Agriculture. Singapore: Springer, pp. 71-91.

Lacirignola C., Adinolfi F., Capitanio F., 2015. Food Security in the Mediterranean Countries. New Medit, 14(4): 2-10.

Lantican F.A., Aragon C.T., Bathan B.M., 2008. Supply Trend and Response Analysis of Selected Semi-temperate and Tropical Vegetables in the Philippines. Journal of the International Society for Southeast Asian Agricultural Sciences, 14(2): 71-85.

McKay A., Morrissey O., Vaillant C., 1999. Aggregate Supply Response in Tanzanian Agriculture. Journal of International Trade \& Economic Development, 8(1): 107-123.

Migliore G., Zinnanti C., Schimmenti E., Borsellino V., Schifani G., Di Franco C.P., Asciuto A., 2019. A Ricardian Analysis of the Impact of Climate Change on Permanent Crops in a Mediterranean Region. New Medit, 18(1): 41-52.

Mostofa M.G., Karim M.R., Miah M.M., 2010. Growth and Supply Response of Winter Vegetables Production in Bangladesh. Thai Journal of Agricultural Science, 43(3): 175-182.

Nerlove M., 1956. Estimates of the Elasticities of Supply of Selected Agricultural Commodities. Journal of Farm Economics, 38(2): 496-509.

Nerlove M., 1958. The Dynamics of Supply: Estimation of Farmer's Response to Price. Baltimore: Johns Hopkins University Press.

Nerlove M., 1979. The Dynamics of Supply: Retrospect and Prospect. American Journal of Agricultural Economics, 61(5): 874-888.

Nichell S., 1985. Error Correction, Partial Adjustment and All That: An Expository Note. Oxford Bulletin of Economics and Statistics, 47(2): 119-129. 
Olubode-Awosola O.O., Oyewumi O.A., Jooste A., 2006. Vector Error Correction Modelling of Nigerian Agricultural Supply Response. Agrekon, 45(4): 421-436.

Ozanne A., 1999. Perverse Supply Response in Peasant Agriculture: A Review. Oxford Development Studies, 27(2): 251-270.

Ozkan B., Kizilay H., Ceylan R.F., 2011. Supply Response for Wheat in Turkey: A Vector Error Correction Approach. New Medit, 10(3): 34-38.

Schiff M., Montenegro C.E., 1997. Aggregate Agricultural Supply Response in Developing Countries: A Survey of Selected Issues. Economic Development and Cultural Change, 45(2): 393-410.

Seale J.L., Zhang L., Traboulsi M.R., 2013. U.S. Import Demand and Supply Response for Fresh Tomatoes, Cantaloupes, Onions, Oranges, and Spinach. Journal of Agricultural and Applied Economics, 45(3): 435-452.

Thiele R., 2000. Estimating the Aggregate Agricultural Supply Response: A Survey of Techniques and Results for Developing Countries. Working Paper No 1016. Kiel Institute of World Economics.

Vembu S.M., Immanuelraj T.K., Dastagiri M.B., 2013. Supply Response Analysis of Major Pulse
Crops in India. Indian Journal of Agricultural Economics, 68(3): 372.

Wani M.H., Sehar H., Paul R.K., Kuruvila A., Hussain I., 2015. Supply Response of Horticultural Crops: The Case of Apple and Pear in Jammu \& Kashmir. Agricultural Economics Research Review, 28(1): 83-89.

Weliwita A., Govindasamy R., 1997. Supply Response in the Northeastern Fresh Tomato Market: Cointegration and Error Correction Analysis. Agricultural and Resource Economics Review, 26(2): 247-255.

Wu J., Adams R.M., 2002. Micro versus Macro Acreage Response Models: Does Site-Specific Information Matter? Journal of Agricultural and Resource Economics, 27(1): 40-60.

Xu C., Shengxiong W., Zhijian Z., Wei S., 2012. A Model for Analysis of Supply Reaction to Price Applied to grapes in China. In: IEEE 2012 International Conference on Systems and Informatics, 19. 20 May, Yantai, Shandong, China, pp. 2559-2562.

Yao S., Zhou Y.H., 2013. An Analysis on the Supply Response of Garlic in China: An Empirical Investigation Based on the Micro Panel Data. Collected Essays Finance Economics, 171(3): 9-14. 